\title{
Thorstein Veblen: A Marxist Starting Point
}

\author{
Kirsten Ford \\ William McColloch
}

Working Paper No: 2011-11

\author{
University of Utah \\ Department of Economics \\ 260 S. Central Campus Dr., Rm. 343 \\ Tel: (801) 581-7481 \\ Fax: (801) 585-5649 \\ http://www.econ.utah.edu
}




\title{
Thorstein Veblen: A Marxist Starting Point
}

\author{
Kirsten Ford \\ PhD Student, University of Utah \\ kirsten.ford@economics.utah.edu \\ William McColloch \\ PhD Student, University of Utah \\ william.mccolloch@economics.utah.edu
}

\begin{abstract}
As existing literature attests, in spite of methodological differences Marx and Veblen draw strikingly similar conclusions regarding production, conflict, and alienation in modern existence. We here attempt to establish that similarity in conclusion stems from similarity in approach. After reviewing the existing literature on a Marx-Veblen methodological reconciliation, we recapitulate Marx's method, making the mediated starting point the locus of discussion. From this vantage point, we then examine Veblen's own approach to analysis in "The Theory of Business Enterprise" and the conclusions that emerge as they resemble those of Marx. In taking a kindred approach Veblen is able to arrive at an understanding of capitalism in accordance with, and complementary to, Marx's rendering of the inverted nature of economic life in modernity.
\end{abstract}

Keywords: Marxism, Institutionalism, History of Economic Thought: Individuals, Economic Methodology: General

JEL Classification: B140, B150, B300, B400

Acknowledgements: Thanks are owed to Dr. E.K. Hunt for his comments. As usual, all disclaimers apply. 


\section{Introduction}

For students working in the heterodox tradition of political economy, where the respective works of Karl Marx and Thornstein Veblen form part of the canon, numerous ostensible parallels between the works of these authors present themselves. Despite this common intuitive supposition, even a cursory glance at the existing literature reveals little consensus. Far from an on-going discussion, the literature more closely resembles the intermittent trading of shots between firmly entrenched camps. Consequently, it would be folly to think that we could resolve this century-long 'debate,' in the context of the present paper; we hope merely to add a new dimension to the debate. Here, we argue the striking similarities that emerge in the analysis and conclusions of both thinkers follow from a commonality in method. While we do not argue that methodologies of Marx and Veblen are, by any means, identical, we insist that the rift between them has been greatly overstated. Specifically, we argue that a parallel can be drawn between Marx and Veblen in terms of their chosen starting points; a parallel only reinforced by their shared perception of the nature of economic life. Of course, the contention that one's point of departure influences the content of a work is a simple truism that would scarcely require proof. Our contention here is that Veblen's chosen starting point in The Theory of Business Enterprise reveals a great deal about his essential methodology, much as Marx's choice to begin Capital with the simple commodity form is far from an arbitrary point of entry. Just as Marx's method serves to demystify capitalism in approaching it from the standpoint of capital, beginning with the commonplace commodity, Veblen's choice to proceed from a historically specific presupposition - the modern 'business man' - allows him to explore the specific character of modern capitalism from the viewpoint of business enterprise. In both cases, we are 
only able to appreciate the inverted reality in which we live, by first adopting such a historicallymediated perspective.

The remainder of this paper is divided into four sections. The first reviews the existing literature on a methodological reconciliation between Marx-Veblen, followed by a recapitulation of Marx's process of inquiry, bringing his mediated starting point to the center of focus. The next section considers Veblen's The Theory of Business Enterprise from this viewpoint, drawing attention to a marked similarity in terms of process and conclusion. We conclude by underscoring the determinant significance of these starting points and underlying visions of economic life to the outcome of economic analysis.

\section{A Marx-Veblen Accord?}

The literature is rife with suggestions that despite certain theoretical and methodological differences between the work of Veblen and Marx, many of their conclusions regarding the operation of modern capitalism may ultimately be reconciled. Here we would voice little disagreement, and in view of this existing body of work we do not intend to add another voice to the chorus. Though we would certainly not deny that a profitable 'Marx-Veblen synthesis' can be achieved despite lingering tensions, our immediate purpose lies elsewhere (but a few representative examples of such efforts may be found in Pluta and Leathers 1978; Dugger and Sherman 1994; Dowd 1974; Sweezy 1958; Stanfield 1989). Namely, we contend that a striking methodological parallel can be drawn with respect to their choice of starting points. 
Logically, the first stumbling block in any attempted reconciliation of Veblen and Marx is Veblen's (1906) explicit commentary on Marx's system. Here Veblen, though generous in his praise of Marx's originality and insights into the operation of modern capitalism, sees Marx as a 'pre-Darwinian' thinker suffering from the same proclivity to adopt a teleological view of history as Hegel. As Veblen rightly suggests, no aspect of Marx's system can be faithfully understood without, at least, a rudimentary comprehension of the entirety of his system and its preconceptions. Regarding these preconceptions, Veblen sees Marx's 'Materialistic Conception of History' as the most consequential. As we are told, "The chief point of interest here, in identifying the materialistic conception with Hegelianism, is that this identification throws it immediately and uncompromisingly into contrast with Darwinism and the post-Darwinian conceptions of evolution" (Veblen 1906, 597). Marx's system, along with that of Hegel, is 'preDarwinian' in that it regards the historical process as "an unfolding by inner necessity." Whereas Hegel traces the progress of geist through history, Marx's 'inversion' of the dialectic consists in his adoption of a material social class as the subject-object of history. It is this primacy given to class struggle in determining the course of history that prompts Veblen's objection. More precisely, Veblen does not object to the inclusion of class struggle as a motive force in history, but rather to the uniquely privileged role assigned to it by Marx. Thus, the ineluctable procession of modes of production in Marx's theory, culminating in a final end when the proletariat recognizes its position as the subject-object of history, marks his system as 'closed,' and unable to appreciate both the dynamism and uncertainty of a true evolutionary approach. By contrast, "[i]n Darwinianism there is no such final or perfect term, and no definitive equilibrium" (582). Veblen, though not limiting his critique to this point, seems to regard it as Marx's most damning 
failure. Indeed, if we were to accept Veblen's judgment that Marx's system is colored through and through by a closed, teleological vision of history, a methodological reconciliation, such as we propose below, would be dismissed out of hand. Fortunately for our thesis, Veblen's conception of Marx is untenable.

As the literature has noted, Veblen's appreciation of Marxian dialectics derives not so much from Marx himself, as from Engels' popularization. ${ }^{1}$ The sort of 'dialectical materialism' to which Veblen objects did certainly flourish following the Second International, as exemplified in the writings of Stalin, and Kautsky, among others. ${ }^{2}$ That a strand of Marxist theory developed in this direction does little to demonstrate the presence of such a crude theory of history in Marx's own system. Moreover, anything like a systematic exposition of Marx's system, which we might demand in support of the charge of historical determinism, is conspicuously absent in the 'Marx-Veblen' literature. Despite this reasoned objection, debate over the methodological compatibility of the two systems has largely turned on Veblen's analysis, with many authors uncritically adopting Veblen's position. Accepting Veblen's characterization of Marx's system, scholars have argued that Veblen's work was a revision of Marx that "substitut[ed] cumulative causation for Hegelian dialectics in explaining economic change" such that "Marxian insights no

\footnotetext{
As E.K. Hunt has noted, Marx himself never uses the term 'dialectical materialism.' Instead, dialectical materialism, conceived as an ontological description of matter in motion, is a conception owing wholly to Engels.

2 Stalin's Dialectical and Historical Materialism is perhaps the ultimate distillation of this mechanistic approach to history. Against Stalin's statement that "the prime task of historical science is to study and disclose the laws of production, the laws of development of the productive forces and of the relations of production, the laws of economic development of society," Veblen's critique is certainly apt. Stalin, J.V. Dialectical and Historical Materialism. III:B
} 
doubt lived on, but they took root in Veblenian ground, and flowered in Veblenian splendor" (Hill 1958, 142).

Much of the subsequent debate over the existence of methodological rift between Marx and Veblen may therefore be reduced to the question of whether Marx's dialectics imply a historical telos. ${ }^{3}$ One voice of affirmation is found in the recent work of Stephen Edgell and Jules Townshend (1993). In their assessment, “there is too much evidence of teleology in Marx's writings for it to be easily explained away" (726). Despite this exclamation, the authors' defense primarily relies on a few brief and de-contextualized quotations. One representative example may suffice for purposes of illustration. The authors reference Marx's statement that “capitalist production begets, with the inexorability of a law of Nature, its own negation." "4 Marx's suggestion is plain enough: An advance beyond the capitalist mode of production would not involve a reversion to the decentralized production of pre-capitalist eras, but rather would require collective ownership of the already centralized means of production. ${ }^{5}$ Nowhere in this passage does Marx suggest that this 'negation of negation' is the final end (telos) of history. Certainly, Marx does suggest that a determinant mode of production would follow capitalist production. This, however, is not the essence of Veblen's objection to Marx. Again, Veblen's concern is that

3 This is, of course, a debate that extends well beyond the existing literature on the intersection of Marx and Veblen, and thus one which we could not hope to fully survey here.

4 Quoted in Ibid, p. 726. In context, the quote reads "The capitalist mode of appropriation, the result of the capitalist mode of production, produces capitalist private property. This is the first negation of individual private property, as founded on the labour of the proprietor. But capitalist production begets, with the inexorability of a law of Nature, its own negations. It is the negation of negation.” Marx, Karl. Capital, Vol. 1, p. 929.

5 That is, capitalism has transcended the asociality of the productive relations which preceded it. What remains to be transcended is the asociality of property relations. 
Marx's dialectic involves a 'definitive equilibrium' or an end of history; an interpretation not directly supported in this passage. Though even a sympathetic reader would hope to be directed towards some passage where Marx suggests that history will reach an 'end,' the authors disappoint.

Against this contention, two lines of refutation have been adopted. ${ }^{6}$ The first of these, developed in part by E.K. Hunt (1979), seeks to distance Marx's use of dialectics from that of Hegel. Drawing on the work of Lucio Colletti (1973), Hunt insists dialectics do not serve as an ontology of matter for Marx, but rather act as an epistemological device that reveals the 'paradoxical' nature of the human condition. This paradox is that human material existence must be understood as a reciprocal relation wherein humans are both the active creators of their own history, and a passive material upon which history acts. Marx's understanding of human labor is illustrative of this point. While all labor is, of course, circumscribed by its historical context, the object of labor is not fully determined by that context, though many of the conditions of labor may be. It is thus precisely because human labor involves the realization of a teleological projection at the level of the individual - i.e. the object of labor exists in the mind before it exists in material reality - that human existence is more than the "inevitable unfolding of history." The

\footnotetext{
6 Interestingly, we find already in Plekanhov (2008) a defense of Marx's system against the charge of teleological history, similar to that which we adopt below. In his work of 1891, The Materialist Conception of History, we are told that "Hegel's synthetic view was at the same time a teleological view. Modern dialectical materialism has completely eliminated teleology from social science. It has shown that man makes his history not in order to march along a line of predetermined progress, and not because he must obey the laws of some abstract (metaphysical, Labriola calls it) evolution. He does so in the endeavor to satisfy his own needs, and it is for science to explain how the various methods of satisfying these needs influence man's social relations and spiritual activity" (13).
} 
mere recognition that history may act upon human social life as an object, is not a denial of human subjectivity, or of historical contingency. The misinterpretation of Marx as a 'dialectical materialist' then owes largely to Engels, and a subsequent generation of theorists; an interpretation belied by a faithful reading of Marx's commentary on Hegel, which we delineate below.

Following the second line of objection, let us suppose that for Marx dialectics do serve as an ontology of matter. This does not imply that the entirety of human social existence is the realization of some grand teleological project. It would seem, for instance, that Marx does regard dialectical contradiction as the ontological basis of matter in motion. In drawing an analogy with the contradictions inherent in the commodity-form, Marx tells us that "it is a contradiction to depict one body as constantly falling towards another and at the same time constantly flying away from it. The ellipse is a form of motion within which this contradiction is both realized and resolved" (Marx 1977, 198). For Georg Lukács (1978), this conception is one demonstration of the precise nature of Marx's departure from Hegelian dialectics. In Marx’s work “[c]ontradiction is thus not only, as with Hegel, the form of sudden transition from one stage to another, but rather the driving force of a normal process" (14). The critical point here is that the admission of dialectics into an ontology of matter need not imply some greater teleological project. Instead, what Marx's dialectical method reveals is that objects, by virtue of being in motion, both preserve and transcend their contradictions. ${ }^{7}$ Human social existence is, however, something

\footnotetext{
$7 \quad$ To reference the relevant example in Marx's system, a contradiction between use value and exchange value is manifest in the commodity. It is the process of circulation that allows this contradiction to be maintained.
} 
more than an object of this kind. That is, while class struggle might be the inevitable consequence of the "contradictions" present in a given mode of production, the outcome of that struggle depends on subjective choices, and historical contingencies. As István Mészáros (2005) has suggested, to suppose that the increasing economic immiseration of the proletariat would mechanistically bring about a change in the mode of production is itself a fetishization of an economic relation. As Mészáros notes, "[e]conomic determinism as a historical hypothesis is a contradiction in terms because it implies the ultimate negation of history. If history means anything at all, it must be 'open-ended"' (116). For Marx, humankind's objective freedom is constituted by the very lack of a singular teleological project in history. Human history is teleological only in the sense that it is a progressive realization of human essence; an essence which Marx (concurrent with Veblen) does not define $a$ priori as either "good" or "bad."

Elsewhere (Cline, Ford and McColloch 2011) we have argued that in rejecting the Idealist dimensions of Hegel's dialectic, Marx implicitly reclaims the materialist dimensions of Aristotle's system. In particular, Aristotle's mediated starting point is seen to resonate in Marx's method and to inform his decision to make the commodity the point of departure in Capital. Our purpose at present is to direct this premise to the mediated starting point as it suggests an underlying essentialism - the parallel between Marx and Veblen that we see underpinning the similarity in their conceptions of capitalism. To this end, we briefly review Marx's basis for beginning analysis from a mediated object in order to lay the foundation for our examination of Veblen's process in The Theory of Business Enterprise. 


\section{Marx's Process}

In examining capitalism's historically specific features Marx proceeds from appearance, or that which is most immediately knowable to $u s$. Once the apparent facts are established he moves beyond the particular aspects of economic life in order to identify their essential nature, revealing what "greater" truths are contained in their existent form. The choice to proceed from the mediated object is perhaps most clearly expressed in his critique of Hegel. As he is often quoted saying of Hegel's dialectic, "With him it is standing on its head. It must be turned right

side up again, if you would discover the rational kernel within the mystical shell.” (Marx [1887] 1992, 29) One of the fundamental ways Marx resolves the Hegelian method into its "rational" core is by connecting the failure of Hegel's objective idealism to perceive the true nature of alienation to his chosen starting point. In Hegel's dialectic, primacy is assigned to the object in thought. Accordingly, the Phenomenology of Mind proceeds from pure Being, void of presupposition, to avoid being deceived by method. For Marx, this is precisely where obfuscation begins. From this perspective, Hegel's ontological position is the result of his failure to grasp the nature of his own alienation, and that of modernity generally. In the Introduction to the Grundrisse, Marx explains the "illusion" that so confounded Hegel. "[In] conceiving the real as the product of thought concentrating itself, probing its own depths, and unfolding itself out of itself, by itself, whereas the method of rising from the abstract to the concrete is only the way in which thought appropriates the concrete, reproduces it as the concrete in the mind" (Marx [1939] 1993, 101). Hence, Hegel mistakes the way nature presents itself for the way in which the concrete comes into being. As Colletti points out, Marx criticizes Hegel for giving predicates an 
autonomous existence, and then turning them into their subjects. ${ }^{8}$ As a consequence, genuine subjects emerge as the result. "Precisely because Hegel starts from the predicates of universal determination instead of the real Ens (subject) and because there must be a bearer of this determination, the mystical Idea becomes this bearer" (Marx [1970] 2009, 24). In this way, Hegel is unable to see that the true subject is the real finite. As Marx says of his own process in the German Ideology, "[t]his manner of approach is not devoid of premises. It starts out from the real premises and does not abandon them for a moment" (Marx and Engels [1932] 1998, 43). To parry the mystification problems that Hegel's system encounters, Marx begins with the actual subject, rather than a predicate divorced from its subject, and perceives its objectification. This is possible because in contrast to the Hegelian world, in which the object has no objective existence outside of knowing itself, for Marx, objects really exist, are external to man and are a basic precondition for the use of his human faculties. In this way, objects are both the prerequisite and occasion for humans to realize their basic nature. ${ }^{9}$

A brief word on Marx's materialism is perhaps worthy of mention, as it is not to be mistaken for those mechanistic forms of materialism and empiricism that he manifestly distanced

$8 \quad$ As he says, "Existence is not a predicate, it is not a concept. The conditions as a result of which something is given us to be known are not to be confused with the conditions as a result of which this something is taken up into thought" (Colletti 1973, 92).

9 This is because for Hegel "the object is only the semblance of an object, a deception, which is intrinsically nothing but knowing itself which has confronted itself with itself, has established in face of itself a nullity, a 'something' which has no objective existence outside the knowing itself." Hence, an object arrives at existence for consciousness inasmuch as it knows it to be something (Marx [1844] 2003, 184). 
himself from. ${ }^{10}$ For Marx, inquiry should neither begin devoid of appearances, or begin and end with them. As is the case when analysis proceeds without presupposition, failure to recognize essence as distinct from existence brings about a mystified view of the capitalist mode of production. The result, whether intended not, of such a mystification is an implicit justification existing conditions. Not only is this is at the core of Marx's critique of Feuerbach, but it is central to his critique of Classical political economy as well. Veblen, of course, wages a similar critique at "neo-classical" economics. In failing to perceive anything beyond the existence of historically specific institutions like private property, lines of inquiry remain wedged where they should begin, amounting to an apologia for existent class relations. As both Marx and Veblen are acutely aware of the errors that come of universalizing particular features of modern life, it is not surprising that certain similarities in approach to analysis exist. Marx begins Capital with the commodity, an "object outside us" readily grasped as such, and from this viewpoint actively works to uncover the veiled relations of production and source of profits in the capitalist mode of production. Having established the context for our comparison, we turn now to a consideration of Veblen's process. In so doing, we hope to corroborate the literature that views Veblen's understanding of the modern age in accordance with, and complementary to, that of Marx by substantiating a parallel in method and essential understanding of economic life.

\footnotetext{
10 In contrasting his own approach with the crude materialism of Feuerbach, Marx explains that equating essence and existence leads Feuerbach to believe that "every exception is expressly conceived as an unhappy chance, as an abnormality. . . Thus if millions of proletarians feel by no means contented with their living conditions, if their 'being' does not in the least correspond to their 'essence' . . this is an unavoidable misfortune, which must be borne quietly. These millions of proletarians and communists, however, think quite differently and will prove this in time, when they bring their 'being' into harmony with their 'essence' in a practical way, by means of a revolution" (Marx and Engels [1932] 1998, 66).
} 


\section{Veblen's Process}

From the outset it should be said that we do not wish to negate, or assign a superficial role to Veblen's evolutionary approach. Rather, we wish to situate it within his own essentialism concerning human nature, where we see Veblen's work to bear most fruit (See Stanfield 1989 for a discussion of Veblen and Marx on the concept of human essence and 'becoming'). To this end, we consider The Theory of Business Enterprise in terms of its basic process. We therefore begin with his mediated starting point, and then direct attention to the conclusion drawn by Veblen that resemble those of Marx. For Veblen, what is, is not eternal, existent from time immemorial. The web of relations, material conditions, and institutional structures within which we carry on the life process has origin, sculpted in time and culture, constituting its present form. Accordingly, existence is in an unremitting state of change, and an understanding of the specific nature of modern economic life requires that nothing be taken as given. Indeed, as Veblen is often quoted, "What is, is wrong" (Lekachman 1994, viii). Yet, what is, is precisely where Veblen begins his examination of the "modern industrial system" in The Theory of Business Enterprise. As he makes clear in the preface: "[T]he following inquiry into the nature, causes, utility, and further drift of business enterprise differs from other discussions of the same general range of facts. . The point of view is that given by the business man's work, - the aims, motives, and means that condition current business traffic. This choice of a point of view is itself given by the current economic situation, in that the situation plainly is primarily a business situation" (Veblen [1904] 1975, I). Beginning with presupposition is of course not arbitrary; it stems from Veblen's 
realization of institutional lag. What is, lags behind productive conditions, frustrating the circumstances necessary to bring human existence more fully in accord with its fundamental nature. Requisite to identifying the discrepancy between institutions and material production is, therefore, a discernment of those features that are peculiar to the system. The 'business man,' as a principal expression of modern existence, plants Veblen's inquiry solidly in the historically specific features of the present economic system, as does the commonplace commodity for Marx. As he says, "In so far as the theorist aims to explain the specifically modern economic phenomena, his line of approach must be from the business man's standpoint, since it is from that standpoint that the course of these phenomena is directed" (4). Moreover, as Marx begins with real premises and does not "abandon them for a moment," Veblen maintains this perspective throughout in order to arrive at an understanding of the way in which the system functions, and concurrently fails to produce the conditions most favorable to essential human life. Through this basic framework, Veblen avoids the obfuscation that results from universalizing the particular.

By means of this process, Veblen uncovers a system replete with conflict. As is too well known to require an exhaustive summary, in examining the shift in the method of business from the "handicraft era" to the "machine age" Veblen hits upon a fundamental contradiction in the modern organization of economic life. ${ }^{11}$ That is, business enterprise, or pecuniary life, thrives on means inimical to machine industry, or material production. This prevents the complex of machine industry from realizing its potential (a potential it is autonomously propelled toward in accord with its own logic) so that the scheme of production in modern life, while sound from the

11 A concise summary of The Theory of Business Enterprise in the context of Veblen's research project may be found in Sweezy $(1958,182-88)$. 
viewpoint of modern business, is "inverted" from the logic of production in general. This antagonistic relation circumscribes the existence of business enterprise; to prevail over or succumb to the machine process proves ephemeral. Should pecuniary life succeed in arresting material production in its pursuit of profit it effectively annihilates its material base. If it capitulates to the logic of industry, it simultaneously stamps out its "spiritual" base - private property. Thus, business enterprise, by virtue of its principality in the organization of machine production, will ultimately hasten its own end. As Veblen explains, "[T]he full dominion of business enterprise is necessarily a transitory dominion. It stands to lose in the end whether the one or the other of the two divergent cultural tendencies wins, because it is incompatible with the ascendency of either" (Veblen [1904] 1975, 400). It is the specific nature of what is to take its place that is uncertain. To be sure, for Veblen human history is a "blind drift," but it is not arbitrary; each historical stage grows out of the previous system in a process of cumulative causal sequence so that as in Marx's system, the material and institutional conditions of present are the basic material for that which will replace it. ${ }^{12}$ Considering the weight that has been given to the charge that Marx's system is "closed" it is worth noting that this conclusion to The Theory of Business Enterprise no more implies determinism in Veblen than a determinant mode of production following capitalism does in Marx, as was discussed above. For Veblen the decline of business enterprise is "a question not of what ought to be done, but of what is to take place"

12 For example, mechanical standardization influences the point of view and consciousness of workers away from individual ownership. But beyond this, "It also furnishes the new terms in which the revised scheme of economic life takes form" as it creates the conditions in which trade unions are formed (Veblen [1904] 1975, 335). 
(377). This simply suggests that business enterprise will be supplanted by another organizing principle to economic life.

Also emerging from Veblen's analysis is an understanding of human social life as an object of history, which, concurrent with Marx, does not deny its inherent subjectivity. It is to be remarked that in neither Veblen or Marx does purposeful human activity imply a historical telos. ${ }^{13}$ When Veblen identifies the worker as a "factor" in the mechanical process he is not suggesting a process in which human life is passively impressed upon by objective forces. Rather, human labor is contained within the machine process and "it is by virtue of his necessarily taking an intelligent part in what is going forward that the mechanical process has its chief effect upon him... His place is to take thought of the machine and its work in terms given him by the process that is going forward"(Veblen [1904] 1975, 307-08). Hence, humans create within inherited conditions, and the reciprocal relation between labor and the labor process creates a revolutionary potential in the modern age. That is, the recognition that private property is the source of productive inefficiency by those employed in industry admits a radical element into Veblen's system. ${ }^{14}$ Here Veblen's insight that labor is both subject and object of history is

13 As Stanfield points out, common to both Veblen and Marx "teleological activity" (purposeful interaction with material life) is basic to human nature and the progression of human life. He contends that "the conscious teleological character of Veblen's instinct of workmanship," and instinctive action in general, of which Veblen himself considers teleological because " it involves holding to a purpose," is no different than purposive human action as a part of human nature in Marx (Stanfield 1989, 98).

14 As was seen in his explicit commentary on Marx's system, Veblen does not object to the inclusion of class struggle as a motive force in history, but instead to the primacy Marx assigns to it. In The Theory of Business Enterprise Veblen admits agreement with Marxist socialists concerning both the inability of the pecuniary classes to adopt a socialistic way of thinking and the radical potentiality in society as "proletarian" in substance. He does, however, wish to distinguish himself on the basis of what constitutes class, which he sees as "a question not of relative wealth, but of work" (Veblen [1904] 1975, 348). Sweezy argues that while Veblen's notion of class comes "closer" to that of Marx in his later work Absentee Ownership, the Veblenian and Marxian notions of class are easily 
not only complementary to Marx's own ideas on the nature of labor, but as Hunt observes, adds an important dimension to Marxism with his thoroughgoing account of imperialism, nationalism, and emulative consumption ${ }^{15}$ as factors that absorb this would-be radical aspect of society (Hunt 1979).

As is well established, for both Veblen and Marx the modern system of ownership lies at the heart of today's power relations and is the institution humanity must eradicate in order to move beyond the existing mode of production and the alienation intrinsic to it. The foregoing analysis makes apparent the basis for such uniformity in conclusion. Essential to the picture of economic life that emerges from The Theory of Business Enterprise is the contradiction between the deepened social nature of production and private property. For Marx, capitalism, in contrast to previous modes of production, achieves objective human interdependence in production, a feature of modern life that is at once concealed by the asociality of property relations fundamental to this mode of production. ${ }^{16}$ For Veblen's understanding of capitalism the intensified interdependence of production in the "modern industrial system" is also fundamental.

reconciled in as much as occupational discipline and class interest are mutually reinforcing (Sweezy 1958). While we would not disagree, it is also worth here noting Marx's own ambiguity pertaining to the definition of social class (See for example Chapter 52 of Capital Vol. 3). For Marx, to conceive of class merely as a relation to ownership would be to treat class as an "abstract universal" in Hegelese. It is only in the subjective moment, that is, through class struggle itself, that classes become manifest as "concrete universals."

15 Emulative consumption, itself solidified into an institution, breeds what Gramsci would have called 'cadres': Individuals whose modestly elevated social standing, and relative comfort, is a consequence of their fealty to the logic of business.

16 For a systematic discussion of Marx's concept of human nature as it underpins the nature of social evolution, see Hunt, E.K. "Marx's Concept of Human Nature and the Labor Theory of Value." Review of Radical Political Economy 14, 2 (1982): 2-25. 
To be sure, when he speaks of the "machine age" he is referring to the complex of industry as a single mechanical process, a scheme of production that grew up alongside the crystallization of the Natural Rights view of ownership into an enforced system of private property. As a result, the "spiritual" foundation of modern economic life tends to obscure the growing discrepancy between the sociality of production and antisocial nature of property relations. Given the efficiency inherent to both the instinct of workmanship ${ }^{17}$ and the machine process, a system capable of providing for the material needs and wants of humanity is a potentiality yet unrealized. Hence, the priority Veblen and Marx as essentialists assign to the interrelatedness of modern production (itself made visible by way of chosen presupposition through which to navigate the specific nature of economic life) brings out from under the coverings of its universalization the "hidden" nature of ownership. Accordingly, both conclude that on condition the present system of ownership persists, human beings are blocked from living in a system more fully in accord with their essential nature.

By way of a final remark, while other parallels may perhaps be drawn from the perspective here proposed, we would like to point to the possibility for future research in this vein to make its center of focus the parallel between Marx and Veblen in terms of contradiction and economic crisis in the shift from the "money economy" to the "credit economy." For both authors, crises are not imperfections of capitalism but are precisely the way it functions. As Veblen says, they are inherent to a system that "is unstable by virtue of the forces at work in its

\footnotetext{
17 The stifling of this essential human instinct, as when labor becomes "irksome," places society in a persistent
} state of "arrested spiritual development." (Veblen 1994, 254) 
own process" (Veblen [1904] 1975, 227). Such analysis could perhaps augment L. Randall Wray's (2007) comparison of Veblen's "credit economy” with Keynes' "monetary economy."

\section{Concluding Remarks}

In summary, Veblen arrives at an understanding of capitalism in accordance with, and complementary to, that of Marx.We have here shown that Veblen's chosen starting point - the modern 'business man' - in The Theory of Business Enterprise reveals a great deal about his essential methodology, as does Marx's choice to begin Capital with the simple commodity form. As Marx's method serves to demystify capitalism in approaching it from the standpoint of capital, Veblen's choice to proceed from presupposition allows him to explore the specific character of modern capitalism from the viewpoint of business enterprise. In both cases, we are only able to appreciate the inverted reality in which we live, by first adopting such a mediated perspective. It is this rendering of the inverted nature of economic life that seems to attract ongoing comparisons of Marx and Veblen in the literature of political economy and history of thought, and it is our hope that the parallel in method here drawn can shed some light on these discussions. 


\section{Bibliography}

Cline, Ford, and McColloch. “An Aristotelian View of Marx's Method.” Working paper, University of Utah Economics Department, 2011.

Colletti, Lucio. Marxism and Hegel. London: Verso, 1973.

Dowd, Douglas F. The Twisted Dream: Capitalist Development in the United States since 1776. Cambridge Mass.: Winthrop Publishers, 1974.

Dugger, W.M. and Howard Sherman. "A Comparison of Marxism and Institutionalism." Journal of Economic Issues 28, 1 (1994):101-27.

Edgell, Stephen and Jules Townshend. "Marx and Veblen on Human Nature, History, and Capitalism: Vive la Difference!” Journal of Economic Issues 27, 3 (1993):721-39.

Hill, Forest C. "Veblen and Marx." In Thorstein Veblen: A Critical Reappraisal edited by Douglas F. Dowd, 129-49. Ithica: Cornell University Press, 1958.

Hunt, E.K. "The Importance of Thorstein Veblen for Contemporary Marxism.” Journal of Economic Issues 13, 1 (1979):113-140.

Lekachman, Robert. Introduction to The Theory of the Leisure Class, by Thorstein Veblen, v - xi. New York: Penguin Books, [1899] 1994.

Lukács, Georg. The Ontology of Social Being: Marx's Basic Ontological Principles. London: Merlin, 1978.

Marx, Karl. Grundrisse, translated by Martin Nicolaus. New York: Penguin Books, [1939] 1993.

Marx, Karl with Friedrich Engels. The German Ideology: Including Theses on Feuerbach and Introduction to the Critique of Political Economy. New York: Prometheus Books, [1932] 1998.

Marx, Karl. Capital, Vol. I. New York:Vintage, [1867] 1977.

Marx, Karl. "The Economic and Philosophical Manuscripts." In Marx's Concept of Man, edited by Erich Fromm. New York: The Continuum Publishing Company, 2003. 
Marx, Karl. Karl Marx: Critique of Hegel's 'Philosophy of Right,' edited by Joseph O’Malley. New York: Cambridge University Press, [1970] 2009.

Mészáros, István. Marx’s Theory of Alienation. London: Merlin, 2005.

Plekhanov, G.V. The Materialist Conception of History, translated by A. Fineberg. New York: Wildside Press, [1891] 2008.

Pluta, Joseph E. and Charles G. Leathers. "Veblen and Modern Radical Economics." Journal of Economic Issues 12, 1 (1978):125-46.

Sherman, Howard. "Marx and Determinism." Journal of Economic Issues15, 1 (1981): 61-71.

Stalin, Joseph. Dialectical and Historical Materialism. New York: International Publishers, 1940.

Stanfield, J. R. "Recent U.S. Marxist Economics in Veblenian Perspective," in Radical Institutionalism: Contemporary Voices, ed. William M. Dugger, 83-104. New York: Greenwood Press, 1989.

Sweezy, Paul. "Veblen on American Capitalism," in Thorstein Veblen: A Critical Reappraisal. Lectures and Essays Commemorating the Hundredth Anniversary of Veblen's Birth, ed. Douglass F. Dowd, 177-198. Ithica: Cornell University Press, 1958.

Veblen, Thorstein. "The Socialist Economics of Karl Marx and His Followers." The Quarterly Journal of Economics 20, 4 (1906):575-95.

Veblen, Thorstein. The Place of Science in Modern Civilization and other Essays. New York: Huebsch, 1919.

Veblen, Thorstein. The Theory of Business Enterprise. New Jersey: Augustus M. Kelley Publishers, [1904] 1975.

Veblen, Thorstein. The Theory of the Leisure Class. New York: Penguin Books, [1899] 1994.

Wray, Randall L. "Veblen's Theory of Business Enterprise and Keynes' Monetary Theory of Production." Journal of Economic Issues 41, 2 (2007): 617-24. 